\title{
THE RELATION BETWEEN THE MOLECULAR STRUCTURE AND GUSHING POTENTIAL OF DEHYDRATED HUMULINIC ACID
}

\author{
by
}

\author{
HENRIK OUTTRUP
}

\author{
Department of Brewing Chemistry, Carlsberg Research Laboratory \\ Gamle Carlsberg Vej 10, DK-2500 Copenhagen Valby
}

Keywords: Beer, gushing, haze, hop degradation products, humulinic acid, isomerised hop extract, protein.

\begin{abstract}
Dehydrated humulinic acid, 2-isovaleroyl-4-(3-methylbut-2-enyliden)-cyclopentane-1.3-dione (DHA) sometimes occurs in isomerised hop extract. The use of any such extract can cause beer gushing. It was attempted to establish whether this gushing-releasing characteristic is related to specific functional groups of the molecule. Two hydrogenated derivatives of DHA, 2-isovaleroyl-4-(3-methylbutyl)-cyclopentane-1.3-dione (IMCD) and 2.4-di-(3-methylbutyl)-cyclopentane-1.3-dione (DMCD) were prepared and their gushing-releasing potential was compared with that of DHA in various types of beer. These three components released gushing but DMCD, probably on account of elimination of a carbonyl group, reacted differently from DHA and from IMCD. The gushing potential of IMCD was lower than that of DHA.

Since both the DHA and the IMCD molecules contain the $\beta$-tricarbonyl system of isohumulone but lack a hydrophilic hydroxyl group on the cyclopentane ring, it was suggested that the gushing potential of DHA was due to the $\beta$-tricarbonyl system and to the absence of the hydrophilic hydroxyl group. The results also indicate that gushing caused by DHA occurs if concentrations of certain DHA protein complexes are sufficiently high in the beer.

It was shown that DMCD-induced gushing is released by DMCD crystals and consequently is different in nature from that of DHA-induced gushing.
\end{abstract}

\section{INTRODUCTION}

The bitter taste of beer is mainly due to the content of iso- $\alpha$-acids (II, Figure 1) originating from the $\alpha$-acids (I, Figure 1) of the hops. In the case of conventional beer brewing, hops are added at the start of wort boiling and the required transformation of the $\alpha$-acids into highly bitter iso- $\alpha$-acids (II, Figure 1) is effected during the wort boiling. For several reasons the utilization of the bitter components of hops is as

Abbreviations: DHA = 2-isovaleroyl-4-(3-methylbut-2-enyliden)-cyclopentane-1.3-dione; DMCD $=2.4$-di-(3methylbutyl)-cyclopentane-1.3-dione; IMCD = 2-isovaleroyl-4-(3-methylbutyl)-cyclopentane-1.3-dione. 


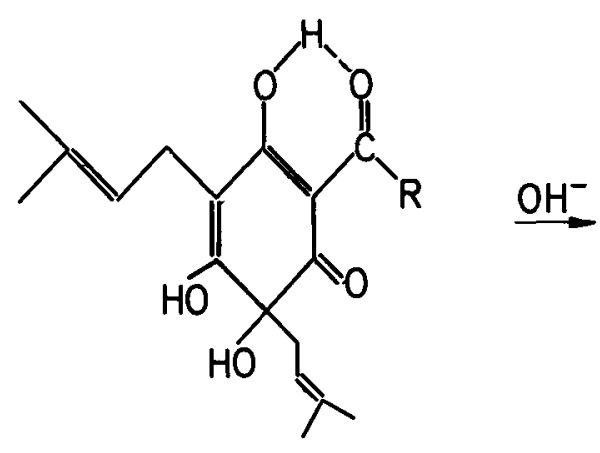

(I) $\alpha$-acids<smiles>[R]c1coc2c1C(=O)/C(=C\C=C(C)C)C2</smiles>

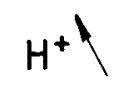<smiles>[R]C(=O)C12CC(=O)C(O)(C1=O)C(CC=C(C)C)(C(=O)CC(C)C)C2=O</smiles>

(II) iso- $\alpha$-acids<smiles>[R]C(=O)C1=C([O-])C(O)C(CC=C(C)C)C1=O</smiles>

$\mathrm{H} \mathrm{O} \mathrm{O}^{-}$<smiles>CO[OH2+]</smiles><smiles>O=C([O-])CC=[V]</smiles>

(III) humulinic acids

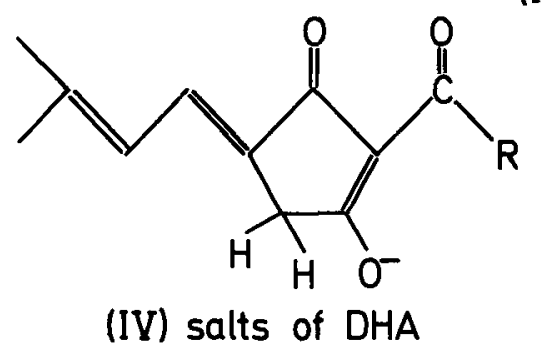

$$
\begin{aligned}
& a: R=-C H=\left(\mathrm{CH}_{3}\right)_{2} \\
& b: R=-\mathrm{CH}_{2}-\mathrm{CH}=\left(\mathrm{CH}_{3}\right)_{2} \\
& c: R=-\mathrm{CH}\left(\mathrm{CH}_{3}\right)\left(\mathrm{C}_{2} \mathrm{H}_{5}\right)
\end{aligned}
$$

Figure 1. Formation of DHA by alkaline degradation of $\alpha$-acid.

$a$-Acids differ in the nature of $R(a, b$ and $c)$. In the case of $b$, the $\alpha$-acid is called humulone.

low as $25-30 \%$ during this type of process. Due to a low $\mathrm{pH}$ the isomerisation is not optimal. Some bitter components will oxidize into nonbitter components, and there is also a drop in the content of bitter components during the fermentation due to adsorption on the yeast. These losses may be prevented if soluble iso- $\alpha$-acid salts are added at a later stage in the brewing process, e.g. prior to the final filtration.

Commercial iso- $\alpha$-acids produced by hydroxylion-catalyzed transformation of the $\alpha$-acids, occasionally cause gushing of the finished beer. 


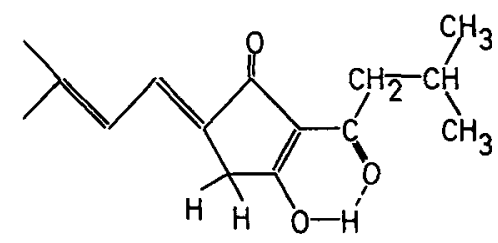

(Vb)

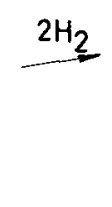

$4 \mathrm{H}_{2}$

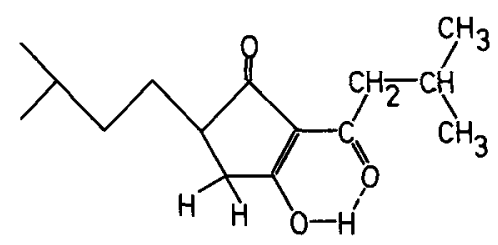

(VI)

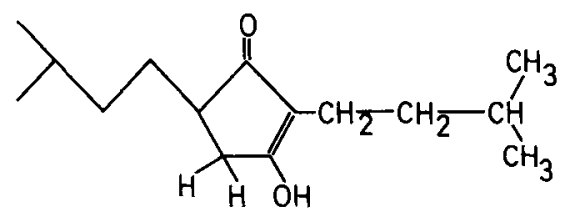

(VII)

Figure 2. Formation of IMCD (VI) and DMCD (VII).

Gushing of beer is an undesirable phenomenon which occurs occasionally in bottled beer at the moment of removing the cap, owing to the instantaneous release of $\mathrm{CO}_{2}$ resulting in overfoaming of some of the content of the bottle. Figure 1 shows that hydroxylions, besides catalyzing the isomerisation, can hydrolyse iso- $\alpha$ acid salts to non-bitter humulinic acid salts (III). Furthermore, strong alkaline conditions lead to an elimination of a water molecule resulting in the formation of salts of dehydrated humulinic acid (DHA, IV); these salts are transformed into acids (V) when added to beer.

Laws et al. (10) analysed an isomerised extract reported to cause severe gushing, and reported that DHA contrary to iso- $\alpha$-acid (II) and humulinic acid (III), was a gushing promotor, even at low concentrations.

It appears from Figure 1 that the DHA molecule differs from both iso- $\alpha$-acids (II) and humulinic acids (III) at two of the carbon atoms in the cyclopentane ring.

In order to investigate the effect of DHA on gushing, two hydrogenated derivatives of DHA, IMCD and DMCD, (VI, VII, Figure 2) were prepared and their ability to induce gushing was compared to that of DHA.

\section{MATERIALS AND METHODS}

\subsection{Solvents and reagents}

The isooctane (Esso Chemicals, ASTM quality) and the toluene (Merck, techn. quality) were distilled before use.

The o-phenylenediamine (Fluka pract.) was recrystallized from toluene before use.

All other solvents and reagents were of analytical grade and were not further purified.

\subsection{Isolation and purification of humulone (I b, Figure 1)}

Humulone was isolated as follows.

Normal hop extract (pure resin extract) was suspended in methanol, chilled to $4^{\circ} \mathrm{C}$ and left for 16 hours whereafter the precipitated wax was discarded.

The filtrate was evaporated under vacuum using a rotary evaporator, and the resulting residue dissolved in toluene. The $\alpha$-acids were precipitated from this solution using o-phenylenediamine in toluene.

The precipitated complex was recrystallized four times from toluene. The $\alpha$-acids were then liberated by treatment with isooctane and diluted hydrochloric acid. The organic phase was washed with saturated sodium chloride solution and dried over anhydrous sodium sulphate. Evaporation under vacuum yielded humulone as a yellow waxy solid, which by countercurrent distribution was shown to contain $95 \%$ humulone. 


\subsection{Preparation of DHA}

Humulone $(88 \mathrm{~g})$ dissolved in methanol $(70$ $\mathrm{ml}$ ) was added to a solution of sodium hydroxide $(5,000 \mathrm{ml}, 2 \mathrm{~N})$ and refluxed for three hours (10). Following chilling on ice, a white yellowish precipitate was formed and isolated by filtration. The precipitate was redissolved in hot water and reprecipitated by adding sodium hydroxide $(6 \mathrm{~N})$. To the precipitate was added isooctane and hydrochloric acid $(4 \mathrm{~N})$ until it totally dissolved. The organic phase was washed with water, dried over anhydrous sodium sulphate and finally filtered through activated carbon. After filtration the solution was evaporated under vacuum to a volume of $200 \mathrm{ml}$ from which chilling on ice produced a precipitate of yellowish DHA crystals. Recrystallization from isooctane produced crystals with a melting point of $87^{\circ} \mathrm{C}$.

The crystals had the following properties: Titration with sodium hydroxide $(0.1 \mathrm{~N})$ produced equivalent weights of 246 and 249 (DHA has a molecular weight of 248). The ultraviolet spectra had $\lambda \max .279 \mathrm{~nm}(\varepsilon=17,200)$ and $322 \mathrm{~nm}(\varepsilon=29,000)$ in alkaline methanol and $260 \mathrm{~nm}(\varepsilon=6,300)$ and $355 \mathrm{~nm}(\varepsilon=34,200)$ in acid methanol.

These data as well as IR and 'H NMR spectra are in accordance with previously published data $(2,6)$.

\subsection{Preparation of IMCD}

Catalyst ( $5 \% \mathrm{Pt}$ on active carbon, $250 \mathrm{mg}$ ) dispersed in dioxane $(25 \mathrm{ml})$ was added to a solution of DHA $(5.0 \mathrm{~g}, 20 \mathrm{mmol})$ in methanol $(175 \mathrm{ml})$. Hydrogen was added until $20 \mathrm{mmol}$ had been absorbed. The reaction mixture was filtered and evaporated under vacuum. The orange residue was dissolved in isooctane and left to crystallize at $-20^{\circ} \mathrm{C}$. The resulting white crystals were recrystallized twice from isooctane. The compound crystallized as waxy needles with a melting point of $26-27^{\circ} \mathrm{C}$.

The compound had the following properties: Titration with sodium hydroxide $(0.1 \mathrm{~N})$ produced equivalent weights of 251 and 252 (IMCD has a molecular weight of 252). The ultraviolet spectra showed $\lambda \max .245 \mathrm{~nm}(\varepsilon=22,700)$ and $265 \mathrm{~nm}(\varepsilon=17,800)$ in alkaline methanol, and $225 \mathrm{~nm}(\varepsilon=12,300)$ and $265 \mathrm{~nm}(\varepsilon=$ $9,650)$ in acid methanol.
These data are in accordance with previously published data $(5,6)$. The structure of IMCD was affirmed by ${ }^{13} \mathrm{C}$ NMR spectroscopy.

\subsection{Preparation of DMCD}

Catalyst (5\% Pt on active carbon, $500 \mathrm{mg}$ ) in dioxane $(50 \mathrm{ml})$ was added to a solution of DHA $(5.0 \mathrm{~g}, 20 \mathrm{mmol})$ in methanol $(150 \mathrm{ml})$. Hydrogen was added until no further absorption occurred. The reaction mixture was filtered and evaporated under vacuum, leaving an orange oil and a white crystalline compound slightly soluble in cold isooctane on the filter paper. After extraction with cold isooctane, the crystals were recrystallized twice from hot isooctane. The crystalline compound had a melting point of $147^{\circ} \mathrm{C}$.

The compound had the following properties: Titration with $\mathrm{NaOH}(0.1 \mathrm{~N})$ gave the equivalent weight of 238. (DMCD has a molecular weight of 238). The ultraviolet spectra showed $\lambda$ max. $272 \mathrm{~nm}(\varepsilon=29,500)$ in alkaline methanol and $251 \mathrm{~nm}(\varepsilon=17,500)$ in acid methanol.

The compound was easily oxidized to a yellow oil in the atmosphere. It produced a pale green colour when treated with $\mathrm{FeCl}_{3}$ in methanol (0.1\%). IR spectroscopy showed the absence of carbonyl groups. ${ }^{13} \mathrm{C}$ NMR spectroscopy showed the presence of two oxygen-bonded carbon atoms.

These observations are in accordance with published data $(5,13)$ for DMCD.

\subsection{Gushing test}

Bottled beer was placed in a crate which was vibrated vertically at an amplitude of $35 \mathrm{~mm}$ and a frequency of $3.8 \mathrm{sec}^{-1}$ at $10^{\circ} \mathrm{C}$ for 48 hours. After two hours rest at $10^{\circ} \mathrm{C}$, the bottles were opened, and the beer quantity gushed determined by weighing.

\subsection{Measuring of surface viscosity}

Surface viscosity was measured according to GARDNER (7), using an oscillating-disc viscosimeter (radius of disc either $1.77 \mathrm{~cm}$ or $2.50 \mathrm{~cm}$, moment of inertia of the system $=1196 \mathrm{~g} \cdot \mathrm{cm}^{2}$ ). 


\subsection{Solubility}

Beer containing crystalline DMCD was stored at $10^{\circ} \mathrm{C}$ for 12 hours. Uncontrolled gushing was avoided by careful handling. After centrifugation the content of additive was measured using a spectrophotometric method (BETHUNE \& RIGBY (3), method I) as the difference between the sample and beer without additive.

\subsection{Colloidal stability of beer}

The bottled beer was stored at $60^{\circ} \mathrm{C}$ for five days after which it was cooled to $0^{\circ} \mathrm{C}$. After 24 hours at this temperature, haze was measured in a hazemeter (Radiometer, type UKM 1d).

\subsection{Analysis of haze}

The nitrogen content was determined by the micro-Kjeldahl method, carbohydrates by the phenol sulphuric acid method and the polyphenol by a modification of the Jerumanis method (9). The content of gushing promotor was determined by quantitative thin-layer chromatography (1) on silicagel (Macherey-Nagel, Polygram SIL-N-HR/UV 254) in toluene-ether 16:1. Before chromatographing, the plates were treated with $1 \% \mathrm{H}_{3} \mathrm{PO}_{4}$ in methanol. DHA $\left(\mathrm{R}_{\mathrm{f}}\right.$ $=0.56)$ and IMCD $\left(R_{f}=0.71\right)$ appear as a brown spot and an orange spot, respectively, developing with $\mathrm{FeCl}_{3}(0.5 \%$ in methanol).

\section{RESULTS}

\subsection{Study of the gushing potential of DHA, IMCD and DMCD}

The gushing of beer containing DHA was examined in three experimental series. Firstly, the gushing potential of DHA was evaluated for two types of beer, a bottom fermented type (Table I, A) and a top fermented type (Table I, B). Secondly, attempts were made to correlate gushing and surface viscosity increase caused by DHA, DMCD and $\mathrm{Ni}^{++}$ions (8), respectively, in beer type $\mathrm{A}$. In the final series DHA and IMCD were compared using the beer types referred to above as well as another bottom fermented beer type (C).

The aim of the initial test was to examine whether DHA was capable of causing gushing of our beer. DHA in ethanolic solution was added
Table I

Gushing released by DHA in bottom fermented (A) and top fermented $(B)$ beer.

\begin{tabular}{ccc}
\hline \multirow{2}{*}{$\begin{array}{c}\text { Addition } \\
\mathrm{ppm}\end{array}$} & \multicolumn{2}{c}{ Beer loss $(\mathrm{g} /$ bottle $)$} \\
\cline { 2 - 3 } & $\mathrm{A}$ & $\mathrm{B}$ \\
\hline- & 0 & 0 \\
10 & 0 & 0 \\
20 & 0 & 2 \\
30 & 7 & 100 \\
40 & 63 & 167 \\
50 & 86 & 167 \\
\hline
\end{tabular}

to the bottles prior to beer bottling. The bottles were submitted to the gushing test (2.6). The results (Table I) show that DHA has a gushing potential for both top and bottom fermented beer and that the top fermented beer was more susceptible to the influence of DHA than the bottom fermented beer (see also LAWs (10)).

GARDNER (7) established a qualitative correlation between gushing and the surface viscosity of beer. In an attempt to test this correlation, nickel ions, a gushing promotor when added to normally hopped beer (8) (as the acetate), DHA and DMCD were added to beer type A. Gushing (2.6) and surface viscosity (2.7) were measured on a 20 min old surface. Table II shows that in

\section{Table II}

Gushing and surface viscosity of a bottom fermented beer to which various gushing promotors have been added.

\begin{tabular}{lccc}
\hline $\begin{array}{l}\text { Gushing } \\
\text { promotor }\end{array}$ & $\begin{array}{c}\text { Addition } \\
\text { ppm }\end{array}$ & $\begin{array}{c}\text { Beer loss } \\
\text { g/bottle }\end{array}$ & $\begin{array}{c}\text { Surface viscosity } \\
\text { csp }\end{array}$ \\
\hline None & - & 0 & 32 \\
\hline & 1 & 0 & 136 \\
$\mathrm{Ni}^{++}$ & 3 & 32 & 237 \\
& 5 & 100 & 386 \\
\hline & 5 & 0 & 150 \\
$\mathrm{DHA}$ & 25 & 0 & 137 \\
& 50 & 0 & 170 \\
\hline & 5 & 0 & 57 \\
$\mathrm{DMCD}$ & 25 & 143 & 30 \\
& 50 & 131 & 35 \\
\hline
\end{tabular}

${ }^{*} \operatorname{csp}=$ centi surface poise, $g \cdot \sec ^{-1}$ 
Table III

Gushing released by DHA or IMCD of beer types A, $B$, and $C$.

\begin{tabular}{cccccc}
\hline \multicolumn{2}{c}{ Addition } & & \multicolumn{3}{c}{ Beer loss (g/bottle) } \\
\cline { 1 - 2 } \cline { 5 - 6 } compound & ppm & & A & B & C \\
\hline \multirow{2}{*}{-} & - & & 0 & 0 & 0 \\
\hline \multirow{3}{*}{ DHA } & 6 & & 0 & 2 & 0 \\
& 14 & & 0 & 4 & 0 \\
& 21 & & 0 & 6 & 0 \\
& 36 & & 0 & 27 & 18 \\
\hline \multirow{3}{*}{ IMCD } & 14 & & 0 & 0 & 0 \\
& 26 & & 0 & 0 & 0 \\
& 44 & & 0 & 0 & 1 \\
& 66 & & 3 & 36 & 71 \\
\hline
\end{tabular}

Table IV

Colloidal stability of beer types A, B, and C to which DHA or IMCD has been added.

\begin{tabular}{cccccc}
\hline \multicolumn{2}{c}{ Addition } & & \multicolumn{3}{c}{ Haze, (EBC units) } \\
\cline { 1 - 2 } \cline { 5 - 6 } compound & ppm & & A & \multicolumn{1}{c}{ B } & \multicolumn{1}{c}{ C } \\
\hline \multirow{2}{*}{-} & - & & 3.6 & 0.6 & 3.3 \\
\hline \multirow{3}{*}{ DHA } & 6 & & 3.9 & 0.7 & 3.1 \\
& 14 & & 3.5 & 1.1 & 3.3 \\
& 21 & & 5.4 & 2.7 & 3.5 \\
& 36 & & 10.1 & 4.9 & 7.5 \\
\hline \multirow{3}{*}{ IMCD } & 14 & & 4.2 & 0.9 & 3.4 \\
& 26 & & 6.5 & 4.0 & 3.3 \\
& 44 & & 7.4 & 4.8 & 7.6 \\
& 66 & & 8.9 & $>12.0$ & $>12.0$ \\
\hline
\end{tabular}

this batch of beer type A which was different from the one used in the test first referred to, DHA was incapable of releasing gushing even though the surface viscosity had increased five times in comparison with the reference. Both $\mathrm{Ni}^{++}$ions and DMCD caused severe gushing but had a different influence on the surface viscosity.

During this test it was observed that beer containing DMCD was extremely hazy, and for this reason solubility testing was applied as described in 2.8. These examinations showed that the solubility of the DMCD in beer is so low that the gushing-releasing DMCD concentrations had produced two-phase systems. DMCD was therefore not included in the subsequent examinations.

IMCD was compared with DHA in a final test comprising the three beer types (A, B and $\mathrm{C}$ ). Table III shows that hydrogenation of DHA to IMCD diminished the gushing potential.

\subsection{Haze formation in beer containing DHA or IMCD}

While it was shown that DMCD could produce haze in beer due to low solubility, colloidal stability tests (2.9) showed that the DHA and IMCD although soluble may both participate in haze formation when beer is stored at $60^{\circ} \mathrm{C}$ for five days (Table VI). Haze was isolated from each of the beer types $\mathrm{A}, \mathrm{B}$, and $\mathrm{C}$. The isolated material was freeze-dried and analysed as described in section 2.10. Nitrogen determination was carried out on dispersions in

Table V

Quantity and composition of haze in beer to which DHA or IMCD has been added.

\begin{tabular}{ccccccccc}
\hline & & & \multicolumn{5}{c}{ Percentage in haze of } \\
\cline { 6 - 9 } $\begin{array}{c}\text { Type of } \\
\text { Beer }\end{array}$ & $\begin{array}{c}\text { Added com- } \\
\text { pound in ppm }\end{array}$ & $\begin{array}{c}\text { mg haze } \\
\text { pr/I }\end{array}$ & $\begin{array}{c}\text { Gushing } \\
\text { comp. }\end{array}$ & $\begin{array}{c}\text { Carbo- } \\
\text { hydrate }\end{array}$ & Protein & $\begin{array}{c}\text { Polyphe- } \\
\text { nols }\end{array}$ & $\begin{array}{c}\text { Uniden- } \\
\text { tified }\end{array}$ \\
\hline \multirow{2}{*}{ A } & DHA & 26 & 13.2 & 2.0 & 28.6 & 36.1 & 1.6 & 31.7 \\
& IMCD & 45 & 104 & 13.1 & 54.7 & 14.8 & 1.1 & 16.3 \\
B & DHA & 26 & 14.7 & 1.4 & 45.6 & 24.6 & 3.5 & 24.9 \\
& IMCD & 45 & 105 & 13.3 & 65.9 & 8.6 & 0.9 & 11.6 \\
C & DHA & 26 & 34.5 & 0.6 & 49.0 & 27.3 & 4.6 & 18.5 \\
& IMCD & 45 & 103 & 12.6 & 38.9 & 17.9 & 1.8 & 28.8 \\
\hline
\end{tabular}


$9 \mathrm{M}-\mathrm{H}_{2} \mathrm{SO}_{4}$ whereas all other analyses were performed on solutions in $6 \mathrm{M}$-urea.

It was seen (Table V) that DHA and IMCD are constituents of the respective hazes, and that all isolates contain carbohydrate and protein (calculated as $6.25 \times$ nitrogen). Even though compositions vary somewhat, it would appear that the content of both DHA and IMCD was at the same level in the three types of haze.

\section{DISCUSSION}

The purpose of this study was to examine why DHA may release gushing of beer i.e. whether any specific functional groups of the DHA molecule are involved.

Using a model system, RoberTs (12), by calorimetry showed that iso- $\alpha$-acids react with beer protein, but that the interaction is weak, being either hydrophobic or involving hydrogen bonding.

Bishop et al. (4), however, found that the concentration of certain proteins (proteoses) and of iso- $\alpha$-acids in the beer foam exceeds the bulk solubility limits resulting in formation of proteose iso- $\alpha$-acid compounds which make the main contribution to the solid reinforcement of the bubble films.

GaRDNER (7) examined the correlation between surface viscosity and gushing and showed that addition of DHA to normally hopped beer caused gushing and an increase in surface viscosity. Further, GARDNER observed that the surface viscosity rose faster when DHA was added to unhopped beer, and suggested that this difference in surface ageing might be due to competition for the surface by other hop compounds in the beer, in this case the iso- $\alpha$ acids.

Finally GARDNER observed that humulone was capable of diminishing gushing as well as surface viscosity of beer with either DHA or nickel-salts added. The $\mathrm{Ni}^{++}$ions associate with iso- $\alpha$-acids and are as such transported to the beer surface.

LAws et al. (10) observed that besides humulone also cohulupone, an oxidation product of colupulone, was capable of diminishing gushing.

Our studies confirmed that DHA may provoke gushing when added to normal beer. IMCD was found to exhibit a similar, but less pronounced potential.

The other hydrogenation product, DMCD, appeared to be a powerful gushing promotor in as much as this compound released gushing in beer which was unaffected by DHA. The surface viscosity of the beer, however, was not affected by DMCD. DMCD is apparently not able to react with beer protein, contrary to the other hop bitter compound mentioned.

Whereas hydrogenation of DHA into IMCD caused saturation of the side-chain at the C-4 carbon atom of the cyclopentane ring, hydrogenation into DMCD in addition caused reduction of the carbonyl group in the side-chain at the $\mathrm{C}-2$ carbon atom. Thus, DMCD lacks the $\beta$ tricarbonyl system common to all other hop bitter compounds referred to. This might indicate that this system is essential for the interaction between protein and hop bitter components in beer.

When such components influence the foam properties of beer in different ways other parts of the molecules should be considered in relation to gushing.

The fact that also IMCD was capable of releasing gushing indicates that the unsaturated side-chain in DHA influences the DHA gushing potential as an intensifier only. In this connection it should be kept in mind that isohumulone like humulinic acid contains a side-chain with a medium degree of saturation at the corresponding carbon atom without being capable of releasing gushing itself. This also indicates that the high degree of unsaturation as such is not responsible for gushing.

An obvious difference between the gushing promotors DHA and IMCD and the nonpromotors is the lack of the hydrophilic group at the C-5 carbon atom. It should be kept in mind that humulone has a phloroglucinol-like ring structure.

According to RoBerts (11), iso- $\alpha$-acids show no particular affinity for specific proteins. BisHop et al. (4), however, isolated solid material from beer foam and precipitations from beer treated with excess of iso- $\alpha$-acids. They observed that both precipitates contained proteoses and that both precipitates were low in polyphenol content, indicating that the foam forming proteoses are characterized by a poor ability to 
bind polyphenols, and that iso- $\alpha$-acids have an ability to combine with such proteoses.

The precipitates isolated in this study occurred only in beer to which a gushing active component had been added. Consequently, these components seem to be of vital importance to the formation of such precipitates. Contrary to precipitates normally found in aged beer the isolates referred to above contained only small quantities of polyphenol.

Thus, it might be concluded that DHA, like iso- $\alpha$-acids, is capable of attaching to proteinaceous components in beer; especially they may attach to the foam forming components.

DHA was not, however, capable of releasing gushing in all of the tests performed in this study. This indicates that in order to release gushing by addition of DHA certain components must be present in appropriate amounts to allow sufficient complex material to be formed.

Summarising, it is suggested that DHA, on account of the presence of the $\beta$-tricarbonyl system, is able to react with proteins and that the gushing potential of DHA may be ascribed to the absence of a free hydrophilic group in the DHA molecule. To release gushing, however, DHA requires the presence of certain proteins in appropriate concentrations in the beer.

The existence of a multi-unsaturated sidechain in the DHA molecule intensifies the gushing potential, but is not as such sufficient forreleasing gushing.

\section{ACKNOWLEDGEMENTS}

I am grateful to Dr. G. GisBons for kind help with the manuscript and to Lizzy Augustsen for drawing the figures. Special thanks to JOAN WINTERBERG for excellent technical assistance.

\section{REFERENCES}

1. Aitken, R. A., A. Bruce, J. O. Harris \& J. C. SEATON: Quantitative analysis of beer bittering substances and hop resins by thin-layer chromatography. J. Inst. Brew. 73, 528-534 (1967)

2. Balwe, T., W. Riedl \& H. Simon: Ringverengungsprodukte von substituierten Phloracylphenonen des Humulon- und Lupulinon-Typs. Chem. Ber. 99, 3277-3287 (1966)

3. Bethune, J. L. \& F. L. Rigsby: Rapid methods for the determination of bitter substances (isocompounds) in beer. J. Inst. Brew. 61, 325-332 (1955)

4. Bishop, L. R., W. R. Inman \& A. L. Whitear: A scientific basis for beer foam formation and cling. J. Inst. Brew. 80, 68-80 (1974)

5. Burton, J. S., J. A. Elvidge \& R. Stevens: The structure of humulinic acid $\mathrm{C}$ and other acidtransformation products of humulinic acids. $\mathrm{J}$. Chem. Soc. 1276-1286 (1965)

6. Durant, W. J.: The dehydration of humulinic acid by alkali. J. Inst. Brew. 72, 404-410 (1966)

7. GARDNER, R. J.: Surface viscosity and gushing. J. Inst. Brew. 78, 391-399 (1972)

8. Hudson, J. R. \& A. D. Rudin: Significance of isohumulone and certain metals in gushing beers. J. Inst. Brew. 64, 317-318 (1958)

9. Jerumanis, J.: Dosage de polyphenols dans les houblons, extrait de houblons, orges et malts. Bull. Anc. Et. Brasserie, Louvain 65, 113-131 (1969)

10. LaWs, D. R. J. \& J. O. McGuinness: Origin and estimation of the gushing potential of isomerized hop extract. J. Inst. Brew. 78, 302-308 (1972)

11. Roberts, R. T.: Colloidal aspects of beer foam. Brew. Dig. 52, 50-58 (1977)

12. RoBerts, R. T.: Interaction between beer protein and isohumulone. J. Inst. Brew. 82, 282 (1976)

13. Wieland, H. \& E. MarTZ: Über de chemische Natur des Hopfenharz-Saüren (III). Ber. 59, 2352-2356 (1926) 